https://doi.org/10.37816/2073-9567-2021-62-246-257

УДК 821.161.1.0

ББК 83.3(2Рoc=Рyc)6

Научная статья / Research Article

This is an open access article distributed under

the Creative Commons Attribution 4.0

International (CC BY 4.0)

(C) 2021 г. Х. М. М. Мохаммед

г. Каир, Египет

«ЧЕЛОВЕК ТРЕТЬЕГО СОРТА»:

К ВОПРОСУ О РЕПРЕЗЕНТАЦИИ ОБРАЗА ЭТНИЧЕСКОГО МИГРАНТА В СОВРЕМЕННОЙ РУССКОЙ ДРАМАТУРГИИ (НА ПРИМЕРЕ ПЬЕСЫ «ХАЧ» У. Б. ГИЦАРЕВОЙ)

Аннотация. В статье на примере пьесы «Хач» (2014) У. Б. Гицаревой рассматривается художественное отражение образа этнического мигранта в современной русской драматургии. Акцентируется внимание на том, каким образом описывается миграция и какими смыслами нагружено это социальное явление в данной пьесе, которая воспроизводит негативный дискурс миграции как духовной катастрофы и как одно из проявлений общего экзистенциального трагизма современного человека. В данной статье приводится обоснование актуальности данной проблемы для литературоведческих исследований. Выбор объекта статьи связан с малой изученностью данной проблемы в современной русской литературе. Специфика пьесы «Хач» в том, что она дает голос мигрантам, вычленяет их из немой массы, что органически вписывается в общую тенденцию «Театра.doc». При анализе сделан акцент на рассмотрении концепта «чужести», реализуемой в пьесе через пространственный хронотоп и художественную предметность. Выявлены и систематизированы дискурсивные средства и механизмы конструирования образа этнического мигранта, восприятие и отношение к нему принимающего сообщества, изучены характеристики, приписываемые мигранту в чужой среде, проанализировано, как тема общественного признания воплощается в повседневном языке, указаны стратегии его поведения в преодолении «чужести». Проведенный анализ показывает, что пьеса «Хач» - это попытка обобщения, встроенная как в социально-психологический, так и в идеологический контекст.

Ключевые слова: современная русская драматургия, У. Б. Гицарева, межкультурная коммуникация, миграция, этнический мигрант, гастарбайтер, дискурс о мигрантах, концепт «чужести», Родина, Чужбина.

Информация об авторе: Хешам Мохаммед Махмуд Мохаммед 一 кандидат филологических наук, доцент кафедры русского языка, филологический факультет «Аль-Альсун» Университета «Айн-Шамс», ул. Аль-Халифа Аль-Маамун, 11566 г. Каир, Египет. ORCID ID: https://orcid.org/0000-0001-7113-1110. E-mail: maro5@ mail.ru

Дата поступления статьи: 06.07.2020

Дата публикации: 28.12.2021 
Для цитирования: Мохаммед X. М. М. «Человек третьего сорта»: к вопросу о репрезентации образа этнического мигранта в современной русской драматургии (на примере пьесы «Хач»У. Б. Гицаревой) // Вестник славянских культур. 2021. T. 62. C. 246-257. https://doi.org/10.37816/2073-9567-2021-62-246-257

В эпоху глобализации и увеличения миграционных потоков в современном социуме на первое место выходит межэтническое общение. Художественная литература во все времена являлась зеркалом событий, происходящих в обществе. Литературное произведение не существует вне культурного контекста, и современное общество не стало исключением. Г. Пранцова отмечает, что «проблема представлений о мигрантах в российской художественной литературе и образ мигранта, передаваемый в сознание читателя, актуальны для нашего общества сегодня» [16, с. 84]. Тем не менее обращение к данной теме в художественных произведениях современников довольно ограничено и не соответствует российской действительности [16].

В России на фоне формирования драматургии «новой волны» появляются «пьесы об определенных социальных группах общества», поднимаются «социальные проблемы...» [13, с. 83]. Первые попытки обращения к теме мигрантов в современной российской драматургии принадлежат «Театру.doc», изображающему реалии современности. Одним из вопросов, которые пытается художественно раскрыть поэтика «Театра.doc», является экзистенциальная сущность миграции. Миграционную тему «доковцы» затронули уже в 2003 г., когда поставили пьесу Александра Родионова «Война молдаван за картонную коробку». Данной теме посвящен и документальный спектакль о жизни трудовых мигрантов «Акын-опера» Всеволода Лисовского в постановке того же театра в 2012 г. Пожалуй, самый известный проект «Театра.doc», раскрывающий жизнь мигрантов, - моноспектакль «Узбек» Талгата Баталова (2013). Главной заслугой «Театра.dос» является предоставление слова самим мигрантам. Отмеченные выше спектакли были революционными - слово мигрантам на сцене до этого никто не предоставлял. Они стали тем рупором, который дал возможность не услышанным ранее голосам оказаться в центре внимания [7].

По мнению М. А. Литовской, герои пьес уральских драматургов - «обитатели “посада", которые, несмотря на свою реальную многочисленность, воспринимались обладателями нормативной культуры как маргиналы, не имеющие в литературе права голоса» $[11$, с. 210$]$. Эти слова в полной мере можно отнести и к героям пьесы «Хач» (2014) У. Б. Гицаревой. Следуя поэтике «Театра.doc», автор пьесы ставит в центр произведения неуслышанные, маргинальные голоса мигрантов, пытаясь взглянуть на все с их точки зрения, передавая их опыт и чувства. Пьеса погружает читателя и зрителя в социокультурный контекст актуального времени. Авторский взгляд «изнутри» позволяет достоверно передать мировидение персонажей-мигрантов, вызвать неподдельное сопереживание адресата.

Цель данной работы - проанализировать художественное осмысление образа этнического мигранта в пьесе «Хач», выявить и систематизировать дискурсивные средства и механизмы конструирования данного образа. Особый интерес представляет тема

${ }^{1}$ Пьеса «Хач» представляла российскую драматургию на международном фестивале в Тобольске, вошла в лонг-лист фестиваля Николая Коляды «Евразия» (Екатеринбург) и в шорт-лист фестиваля «Любимовка» (Москва). «Хач» был отмечен театральным критиком Павлом Рудневым в личном рейтинге важных театральных событий 2013-2014 гг. Пьеса «Хач» - победитель в конкурсе Национальной премии и фестиваля «Золотая Маска» в номинации «Выбор зрителей» (в рамках специальной драматургической премии «Конкурс Конкурсов 2015»). 
Чужбины. При этом отдельного внимания заслуживают не столько естественные, природно-пространственные характеристики Чужбины, сколько социально-психологическое самочувствие мигранта. Прежде чем рассматривать художественные аспекты заявленной проблемы следует отметить, что одним из главных интерпретационных понятий в исследовании миграционной темы выступает «чужесть». Анализ пьесы «Хач» в контексте концепта «чужести» в ракурсе культурологического подхода является наиболее важным для реализации поставленной цели. Литературовед В. Роте в характеристике архетипа «Человека-Чужака» выделяет основные аспекты его «отчуждения-чужести», включая не столько антропологические, сколько социальные факторы, среди которых выделяется “чужак как представитель другой расы или национальности - чужеродец". Такое состояние субъекта он определяет термином «социальная внепространственность» [15].

Пьеса «Хач» рассказывает о так называемых «понаехавших», «приезжих», о людях, по разным причинам, но вынужденно покинувших свою страну и попавших в чуждое им окружение. Произведение построено методом монтажа, оно состоит из 8 сцен и 7 вставок, оформленных как интервью. На протяжении всего сюжета перед нами предстают самые разные люди, но в каждом из них подчеркнута национальность. Событийные сцены - это человеческие истории, развивающиеся параллельно в двух сюжетных линиях и объединенных в финале.

Первая повествует о русской девушке Кате и ее муже колумбийце Себастьяне. Молодая семейная пара, проживающая в среднем российском городе, столкнулась с проблемой тяжелой жизни в России из-за постоянного русского национализма, проявляемого в отношении «чужих».

Сюжет начинается с диалога молодых супругов о культурных несоответствиях. Данный диалог является в пьесе ключевым моментом в раскрытии образа восприятия этнического мигранта с позиции художественного концепта «чужести». В этом контексте примечательна этническая метафорическая модель, в основу которой положено представление о национальной идентичности, проявляющееся в классифицировании людей посредством лингвокультурологической оппозиции «Свой / Чужой» [4, c. 39-41]. В диалоге супругов отчетливо наблюдается представление «русских» о своих / чужих: «СЕБАСТЬЯН. А почему без войны ты говоришь “свой” и “чужой”? КАТЯ. В России всегда война < ..> СЕБАСТЬЯН. Но ты же говоришь “свой” и “чужой” о своих, а не про тех, кто снаружи. КАТЯ. У нас очень много чужих хотели стать своими...» [5, c. 89]. В данном диалоге воплощена мысль о национальном самосознании, формируемом за счет наличия фигуры виновного, «внешнего врага»: «СЕБАСТЬЯН. Потому что вас все хотят? КАТЯ. Потому что хотят нашу землю, а нас не хотят» [5, с. 89]. Б. Дубин отмечает, что «неприязнь к тем, кто вовне, - лишь проекция конфликтов внутри» [8, c. 349]. Комментируя эти слова, Н. Барковская замечает: «Образ “чужака” конструируется из наших собственных фобий и страхов, подавленных комплексов и пережитого опыта насилия» [2, с. 356]. Рефлексирующий взгляд «чужого», взгляд со стороны обнаруживает парадоксы указанного самосознания. В роли постороннего разоблачителя оказывается колумбиец: «КАТЯ. <..> Александр Пушкин. Он, кстати, тоже из приезжих. Из черных. < ..> СЕБАСТЬЯН. Поэт. <.. > У вас к нему, к чужому, гордость, а он — не ваш. <..> Вы любите один, а главный у вас всегда другой. <..> Вы любите Броцки, а главный - Пушкин. < ..> Я не понимаю, почему я чурка, если я Себастьян!» [5, с. 89]. Уже в начале пьесы автор предоставляет возможность герою-мигранту проговаривать свои «слова», которые воспринимаются как попытка разобраться в природе негативного отношения к «приезжим». 
Себастьян - типичный «чужестранец», утративший Родину. Его образ — олицетворение драмы современного мигранта, пытающегося устроить свою судьбу в новом для себя мире, который не принимает его. В его характере воплощены компоненты социального стереотипа «этнический мигрант» и культурные коннотации вокруг «иноземца». Себастьян концентрирует на себе все аспекты «чужести». Отличный от коренного населения и визуально, и по манере поведения, колумбиец, еще не освоивший русский язык и совершающий речевые ошибки, вынужден терпеть открытую враждебность со стороны местных жителей. В отношении него проявляют физическое насилие, презрительно называют «чурка» - этнофолизм [9], использующийся исключительно в пейоративном смысле, служащий своеобразной стигмой (стигматизирующий дискурс). Уместно отметить, что ненормативные наименования национальностей используются принимающим обществом в качестве маркера констатации инаковости в отношении представителей других национальностей, как оскорбление, призванное подчеркнуть иноэтническое происхождение оскорбляемого [1] (вербальная агрессия). В данной ситуации важную роль играет противопоставление Обидчик / Жертва: «СЕБАСТЬЯН. Меня поймали сегодня <..> в арке. Сказали, что я чурка $<\ldots>$ они стали бить. <..> КАТЯ. (видит многочисленные ссадины). Мужик, ну как же так... > ..> СЕБАСТЬЯН. Так. Так. Каждую неделю так и вот так. (Мешает руками, изображая удары)» [5, с. 89-90]. Для героя «новое» пространство - источник постоянного страха и обиды. В пьесе показано, как в условиях неприкрытого расизма (расистский дискурс) не исключены деформация личности мигранта и формирование в нем комплекса неполноценности. Себастьяну приходится жить в иноэтничной и инокультурной среде, в которую он никак не может вписаться и которая слишком сильно давит на него. Осознание героем своего статуса порождает у него ситуацию отчуждения: «СЕБАСТЬЯН. Я не могу больше. <.. > я всегда здесь слабый. < ..> За меня всегда стыд» [5, с. 90]. В ответной реплике Кати заключается одна из главных идеей пьесы - если человек вне «своего» пространства, то на него всегда будет поставлено «клеймо»: «КАТЯ. Ну, < ..> а куда ты хочешь? К тебе нельзя. А в любой другой стране мы оба будем слабыми» [5, с. 90]. Автору пьесы удалось передать внутреннее состояние человека, желающего утвердиться как личность и закрепиться в новой реальности, но постоянно наталкивающегося на глухую стенку непризнания (социальное дистанцирование): «СЕБАСТЬЯН. Катюшкинья, но ведь я не чужой? КАТЯ. Мне не чужой. А всем остальным... » [5, с. 90].

Нельзя не согласиться с Г. Пранцовой в том, что «образ мигранта складывается не только (и не столько) на основе социальной практики и наблюдений отдельных субъектов. Решающую роль в данном процессе играет общественное мнение» [16, c. 84]. Б. Дубин замечает, что «этнический негативизм к “понаехавшим" - не столько результат непосредственного опыта контактирования с ними, сколько выражение установки» $[8$, с. 350]. В этом плане обращает на себя внимание интервью, которое берут у молодого парня, участвовавшего в избиении колумбийца и участника экстремистской группы, проповедующей идеи национал-неофашизма. Группа отлавливает «черных», как они их называют, и избивает их. Интервью иллюстрирует стереотипы о мигрантах, существующие и воспроизводящиеся в публичном дискурсе. Выстроенной в сознании принимающего общества оптике свойственны расистский негативизм и ксенофобия в восприятии мигрантов, «нежелательных элементов», которых обывательское (постколониальное) сознание подвело к общему знаменателю (стереотипизация образа), называя их всех «черными»: «ПЕРВЫЙ. Как вы их называете? ВТОРОЙ. Мы никогда 
не говорим “чурки”, “ары”, “хачи”. Только просто “черные”» [5, с. 90]. По мнению Л. Е. Весниной, в цветовой характеристике «черные» заложен отрицательный полюс оценки понятия «мигрант» [4, с. 40]. Данный образ, как замечает М. Ю. Свинкина, выполняет разграничивающую функцию и служит для упрощения и генерализации восприятия [17].

В дискурсе ксенофобии образ мигранта представлен как опасность, несущая угрозу национальной идентичности (демонизация образа). Мигрантофобия выступает как страх: «ВТОРОЙ. Они сжирают нас, как в Штате сожрали Детройт. < ..> У моей сестры в классе четверо белых, остальные черные...» [5, с. 90]. В данном отрывке заметим, как использованная метафора вторжения, захвата, оккупации («сжирают», «сожрали») является средством концептуализации мигрантов. Примечательно, что такие настроения по отношению к этническим мигрантам характерны не только для националистов, но и для рядовых людей. В интервью с ветераном, служившим в свое время на советско-турецкой границе, читаем: «ПЕРВЫЙ. Ты считаешь себя националистом? ВТОРОЙ. < ..> нет. Я просто терпеть не могу черных» [5, с. 98].

Катя и ее муж «маются» в «ксенофобской» России. В поисках лучшей доли Себастьян уговаривает жену уехать в Австралию, выступающую в его сознании перспективным местом и мечтой о прекрасном будущем, где можно преодолеть социальную иерархию и расовые барьеры. Однако после переезда это представление меняется. Не совпадающая с ожиданием реальность оказывается пессимистичнее, чем ожидалось. Супруги прибегают к стратегии вписывания в пространство миграции в противовес состоянию «безместности». Они стремятся вписаться в новый социум, даже ценой сознательного понижения личного статуса. Так, 27-летняя Катя - кандидат наук, обладающий знаниями пяти иностранных языков: в России она востребована как переводчик, а вот за границей языки ей оказываются не нужны. Катя вынуждена оставить карьерные амбиции и зарабатывать на жизнь путем предоставления клининговых услуг, она трет перила у богатеев (вспомним ее слова: «<... пока ты чужой, тебе придется этим заняться» [5, с. 89]). Катя работает у американки Ким, проживающей в Австралии с мужем чехом немецкого происхождения Хелфридом. Себастьяна же, который работает также не по специальности (инженер по образованию), на работе обманули, не заплатили: «КАТЯ. Я очень благодарна, что ты меня < ..> взяла. Сейчас так трудно, мужа на работе обманули, не заплатили. $<\ldots .>$ КИМ. Так пусть подаст в суд. КАТЯ. < .. > Он колумбиец. КИМ. О мой Бог! Еще и он колумбиец, мало того, что ты русская! Да, здесь ему скорее подбросят наркоту и посадят, чем он выиграет дело. Русская и колумбиец тут........ [5, с. 92].

Пьеса демонстрирует то, что, когда человек оказывается не на своем месте, он чувствует себя заложником собственной национальности, несмотря на свои лучшие качества, вне зависимости от уровня образования и степени своей цивилизованности: «Тот, кто ты есть, ты можешь быть только дома» [5, с. 99], — и что на Чужбине, в состоянии «выброшенности» с Родины, каждый может стать «чужим» и тогда опускается в низ социальной лестницы: «КИМ. Знаешь, Катя, чужой - это везде третий сорт. Мой муж здесь третий сорт, потому что он чех немецкого происхождения, европеец. <...> Они его считают третьим сортом» [5, с. 93]. При таком замкнутом круге национальной иерархии, этнического расслоения общества каждый кому-то третий сорт, сегрегация по принципу «человек человеку... хач!». Так ощущают себя и русские в Европе: «А русские... они бедные. Их европейцы считают третьим сортом» [5, с. 93], и американцы в мусульманском мире: «Штаты для всего мусульманского мира третий сорт» 
[5, с. 93]. Автор пьесы поднимает вопрос «третьего сорта людей» в планетарном масштабе, подтверждая, что такие люди могут быть везде, вне зависимости от национальности и страны. Решая важную для поэтики пьесы проблему отчуждения, У. Гицарева включает в произведение характеры разных национальностей и, таким образом, расширяет рамки «аутсайдерства» этнического мигранта.

Концепт «чужести» получает свое особое воплощение в оппозиции «Родина Чужбина». Оказавшись в статусе мигранта, Катя испытывает чувство «покинутости». В данном состоянии ее картина мира состоит из двух составляющих: ностальгических настроений и желания вернуться на родную землю. Только вдали от Дома героиня начинает чувствовать себя русской. Ностальгией по Родине и чувством потери Дома пронизан ее телефонный разговор с Россией: «Боже мой, какое счастье! Как это здорово говорить “Боже мой”, а не “мой Бог”! Как хорошо говорить по-русски!» $[5$, с. 96] (язык является «домом бытия» по формуле Мартина Хайдеггера). С тоской вспоминает она простые вещи, связанные с Родиной: «Я очень хотела сливочного мороженого <...> Я попросила сливочное. Они спрашивают: как это? Со вкусом молока? И дали мне какую-то водянистую ледышку из сухого молока. Я фыркнула...» [5, с. 96]. Мучаясь невостребованностью и ощутимой «второсортностью», Катя в состоянии полного разочарования понимает, что миграция не стала для нее спасением, что здесь, на Чужбине, многие идеалы недосягаемы, и желает вернуть утраченный мир: «Я хочу домой <..> Я хочу вернуться в Россию» [5, с. 100]. Пьеса иллюстрирует, что наложение «инаковости» как «чужести» помещает этнического мигранта на периферию общества, вытесняет его на обочину жизни, к числу «живущих на окраинах» (социальная маргинализация). Налицо образ «маленького человека», для которого большое потрясение потеря своего мира, потеря дома (как концепции, символа и реальности), имманентное чувство психологического отчуждения и метафизической «бездомности». Понятие «Чужбина» - «это не только метафорическое место миграции, но и символическое пространство отчуждения. Оно отсылает одновременно к географической реальности и к состоянию трансцендентной бездомности» [12, с. 34].

Для Себастьяна возвращение на Родину вообще не имеет смысла: «СЕБАСТьяН. $<\ldots>$ У меня нет везение с Родина» $[5$, с. 100]. Герой оказывается в состоянии «чужой среди чужих» [18, с. 195], т. е. отчуждение от Родины и одновременно неприятие новой средой. Мигрантская жизнь, в результате, становится промежуточным существованием, в котором состояние "in-betweenness" пронизывает все сферы бытия мигранта [3]. Речь идет о феномене двойной «чужести»: изъятый из родной культуры, мигрант остается так до конца и не принятым новой культурой. В ситуации вынужденного переселения расставание с Родиной может обречь мигранта на вечное скитание: «КАТЯ. < ..> И сколько мы так будем ездить? СЕБАСТЬЯН. У тебя есть язык. Ты можешь везде. КАТЯ. Это ты можешь везде, ты привык быть бездомным, ты привык быть беженцем. СЕБАСТЬЯН. Да мы должны бегать» [5, с. 100]. Акцентируя мотив вечного странничества героев, пьеса показывает, что вся неустроенность мигранта сливается в единый комплекс человека-скитальца, утратившего не только Родину, но и признание и уважение людей в принимающем социуме.

Катя возвращается в Россию, которая встречает ее не по-матерински жестко. У нее крадут чемодан с деньгами и документами, и она оказывается в комнате полиции при московском вокзале. Там она знакомится с двумя трудовыми мигрантами из Таджикистана и Абхазии, которые ее выручают. Абхазец отдает ей свой нательный крест, память от любимой, чтобы Катя смогла приобрести билет до дома. 
Один из основных мотивов пьесы - мотив психологической травмы вынужденной миграции - реализуется в пьесе на примере еще более отчужденных персонажей, которые остро ощущают свое одиночество и воспринимаются местными жителями как «чужаки». Вторая линия в пьесе показывает историю таджика Мансура и абхазца Тамаза, которые кладут плитку в Москве. Они придумывают безумную идею, как заработать зимой деньги в Москве, - «Зимний банан». В пьесе рассказывается, как полиция разогнала этот странный аттракцион, приняв его за хулиганство и издевательство.

История Мансура и Тамаза представляет собой живой портрет трудовых мигрантов, которые «отправляются в крупные российские города за заработком, подчиняясь общим решениям своих домохозяйств и определенному моральному императиву обеспечить оставшихся на родине близких» [12, с. 34]: «МАНСУР. < .. > Меня первого сюда отправили, хоть я второй сын. Нас восемь, мама восьмого рожала и - баммм! Все есть хотят» [5, с. 91]. Хотя эти два персонажа в пьесе фигуры комические, их история реализует образ вынужденных переселенцев, которые, проходя все круги миграционного ада, борются за выживание. Негативный дискурс о миграции принимается мигрантами, которые говорят о своем отъезде с Родины как о вынужденном решении. В их речи прослеживается коммуникативная стратегия аргументирования [10]. Каждого из них сдвинула с насиженных мест бедность: «МАНСУР. У меня страна бедная, богатый был, не приезжали бы...» [5, с. 101] и война: «ТАМАЗ. < .. > Если б грузин нас не разбил, я бы дома сидел» [5, с. 91].

На примере этих персонажей пьеса «Хач» иллюстрирует, что проблемы трудовых мигрантов являются отражением внутреннего неблагополучия российского общества. Помимо бедственных бытовых условий эти два гастарбайтера ${ }^{2}$ испытывают травму от попадания в недружественное окружение, в среду, где они вынуждены жить с осознанием своей «чужести»: «... Танцевать хотел. Не пустили, сказали “черный”» [5, c. 91], «Нас на чужие машины не садят. Мы черные» [5, с. 92]. В конце пьесы продавец небесных фонарей предлагает купить Мансуру и Тамазу «бумажные купола желания». Когда Мансур и Тамаз отказываются покупать фонари с «чудовищной скидкой» 一 денег нет, русский продавец, высказывая в резкой форме свое отношение к приезжающим в другую страну, бросает им в лицо: «Да какой я тебе братан? Да вы задолбали нас всех тут уже, хачи херовы! Че вам дома не сидится? Плюнуть скоро некуда уже будет, в черную морду сразу попадешь! Работать из-за вас уже негде, везде хачи одни! < ..> Я тут хозяин, я тут дома!» [5, с. 120]. В этом эпизоде видно, кроме бытующего социального стереотипа об ограничении из-за мигрантов рабочих мест, специфическое обыгрывание оппозиции, выражающейся в противопоставлении «хозяева» и «гости». Эксплуатация метафоры «Россия - это наш дом (куда беспрепятственно вторгаются иноземцы)» в дискурсе о мигрантах является эффективным средством усиления в общественном сознании негативного к ним отношения. Мигранты изображаются в виде наглых гостей, выживающих хозяев из родного дома.

В истории Мансура и Тамаза описывается еще одна причина тяжести жизни на Чужбине. Речь идет о взаимоотношении гастарбайтеров с правоохранительными органами в России как стране-реципиенте [6]. В пьесе показано, как в восприятии представителями власти иноэтничных трудовых мигрантов доминирует стереотипный взгляд на гастарбайтеров как «нелегалов», а последние, в свою очередь, испытывают к тем глубокое недоверие: «...у них план. По план надо посадить кого-то < ..> надо

${ }^{2}$ Под гастарбайтерами имеют в виду иноэтничных мигрантов, занятых неквалифицированным, низко оплачиваемым трудом [2]. 
ловить кого-то» [5, с. 97]. Автор пьесы сатирически показывает высокомерие представителей «принимающей стороны». Главным средством создания зрелища выступает речь, «властный дискурс», отчужденный от субъекта [2, с. 363]. О. А. Косова определяет этот тип коммуникативных стратегий отчуждения как стратегию власти и подчинения [12], что подтверждается представленными ниже примерами, показывающими, что именно речь маркирует мигранта, проводя границу между «своим» и «чужим».

Произвол полицейских в отношении гастарбайтеров показан в эпизоде с прикрытием склада на «оптовке», где ночевали Мансур и Тамаз: «...Мне капитан говорит: “Ну, выпустим мы их, они опять по нашему району гонять будут, надо их выселить. <..> Я нашел, эпидемку вызвал, нарушение подобрал, прочистили. <..> у нас им жить больше негде"» [5, с. 92]. В словах полицейского, совершившего облаву, слышатся антиэтнические настроения, что воспринимается как дискриминация мигрантов по расовым признакам: «...бей их, мало с нас орды! Гони их по кишлакам! Те услышали, и началось. Это наши ментов боятся, а хачам менты - не менты, похер. Короче, повязали их и - в обезьянник» [5, с. 92]. Здесь обнаруживаются и концептуальные метафоры, характерные для авторитарного и расистского дискурса, в уподоблении мигрантов хищникам: «Они ж, знаешь, как воронье, где один, там и другие» [5, с. 92]. В приведенном примере демонстрируются две тактики, посредством которых реализуется коммуникативная стратегия власти и подчинения. Тактика дистанцирования; на уровне языка сотрудник полиции использует в репликах местоимения «они», «наш» («они опять по нашему району гонять будут»). Тактика оскорбления; он с нескрываемым пренебрежением указывает на социальную позицию трудовых мигрантов («а хачам менты - не менты»). Концепт «чужести» реализуется через экзотизацию (национальную и культурную) трудовых мигрантов как особой, отличной от остальных социальной группы, что помещает их в ситуацию отчуждения.

В другом эпизоде столкновения этих двух гастарбайтеров с пограничником при проверке документов на границе России с Абхазией показано, как для некоторых «служителей правопорядка» трудовые мигранты - своего рода питательная база: «МАНСУР. < ..> Деньги он все взял? ТАМАЗ. Взял. Карманы выверну, хочешь? МАНСУР. Выверни... Да вижу, вижу» [5, с. 97]. Данный отрывок подчеркивает, что проявление расовой ненависти и ксенофобии есть маскировка и оправдание своих действий, цель которых - заработок [4].

В образе Мансура и Тамаза ярко выражена отмеченная выше тема тоски по утраченной, потерянной Родине (эта тема пронизывает все сюжетные линии пьесы). Герои не могут найти гармонию в своей «новой» жизни, и воспоминания о Родине являются единственным утешением для них. Родная страна теперь кажется привлекательней, чем эмигрантский быт, отторгающий их. Они остро переживают одиночество на Чужбине. Это обстоятельство подталкивает героев к идеализации родных мест, а также подстегивает интерес к культурным традициям Родины. Концепт «чужести» реализуется здесь в рамках оппозиции «Родина - Чужбина» через пространственную категорию, которая обретает у героев экзистенциальный смысл. Пространство разделено на «здесь» и «там», на «у нас» и «у вас»: «КАТЯ. <..> Вы, наверное, думаете, вам не повезло с родиной... МАНСУР. Как не повезло? Везло нам, очень везло. У нас тепло, у нас к отца уважение. У нас пить, курить нельзя, потому что стыдно, Аллах видит. У нас язык какой красивый» [5, с. 101]; «МАНСУР. Сильно хорошо в твоя Пицунда? ТАМАЗ. Только там и хорошо» $[5$, с. 91$]$. 
Таким образом, проведенный анализ показывает, что пьеса «Хач» поднимает одну из больных проблем современного мира - проблему миграции. Транслируя живой голос мигрантов, пьеса, без преувеличения, является ярким примером художественного описания культурных проблем миграции современной российской драматургией. Пьеса обобщает эту проблему в социально-психологическом и в идеологическом контекстах и воспроизводит негативный дискурс о миграции, воспринимаемой как духовная катастрофа, как одно из проявлений общего экзистенциального трагизма современного человека. В пьесе воссоздается яркая картина географического, социального и психологического отчуждения людей, покинувших Родину в поисках лучшей доли, но обретших на Чужбине лишь острое ощущение заброшенности, забытости, изгойства, территориальной и культурной маргинальности. Автору пьесы удалось запечатлеть трагизм положения этнического мигранта, который рассматривается как «человек третьего сорта». Данная пьеса предлагает сменить эту ставшую привычной оптику и напоминает о том, что люди делятся не по цвету кожи, а на хороших людей или плохих. Главную сентенцию пьесы произносит именно таджик-плиточник Мансур: «А какой я черный? Душа-то белый. Аллах говорит, только у души цвет есть»³.

\section{СПИСОК ЛИТЕРАТУРЫ}

1 Баринова А. О. Языковая репрезентация собирательного образа мигранта в российском обществе // Вопросы психолингвистики. 2013. № 18. С. 174-181.

2 Барковская Н. В. Право на голос: образ мигранта в современной русской поэзии // Новый филологический вестник. 2019. № 3 (50). С. 363-376.

3 Бугаева Л. Д. Мифология эмиграции: геополитика и поэтика // Ent-Grenzen. Intellectuelle Emigration in der russichen Kultur des 20 Jahrhunderts / За пределами. Интеллектуальная эмиграция в русской культуре XX века / изд. L. Bugaeva, E. Hausbacher. Frankfurt am Main: Peter Lang, 2006. C. 51-73.

4 Веснина Л. Е. Метафорическое представление миграции в реакциях свободного ассоциативного эксперимента // Лингвокультурология. 2010. Вып. 4. С. 31-47.

5 Гицарева У. Хач // Современная драматургия. 2014. № 4 (октябрь-декабрь). C. $88-102$.

6 Гладарев Б. С., Цинман Ж. М. Милиционеры и гастарбайтеры: уличные практики перераспределения ресурсов // Социологический журнал. 2015. № 1. С. 37-62.

7 Гордиенко Е. И. Непрофессионалы на профессиональной сцене: эстетика обыденного в современном театре и танце // Практики и интерпретации. 2020. Т. 5 (1). С. 82-99.

8 Дубин Б. Россия нулевых: политическая культура, историческая память, повседневная жизнь. М.: РОССПЭН, 2011. 391 с.

9 Коробкова О. С. Маркеры вражды в номинациях этнической принадлежности: социо-лингвистический аспект // Известия РГПУ им. А. И. Герцена. 2009. № 111. C. 200-205.

10 Косова О. А. Коммуникативная ситуация отчуждения: автореф. дис. ... канд. филол. наук. Иркутск, 2010. 18 с.

11 Литовская М. А. Многоречие в пьесах Николая Коляды: социальный аспект // Русский язык в многоречном социокультурном пространстве. М.; Екатеринбург: ФЛИНТА; Изд-во УрФУ, 2017. С. 206-219.

${ }^{3}$ В достоверном хадисе (изречении) пророка Ислама Мухаммада говорится: «Поистине, Аллах (т. е. Бог $-X . M$.) не смотрит ни на тела ваши, ни на ваше обличье, но смотрит Он на сердца ваши и дела ваши» [19, с. 1987]. 
12 Малахов В., Олимова С., Симон М. Творчество мигрантов как проблема социологии культуры: выходцы из Таджикистана в России // Неприкосновенный запас. 2018. № 3 (119). С. 30-54.

13 Матвиенко $K$. Новая драма в России: краткий экскурс в недавнее прошлое и эскиз настоящего // Петербургский театральный журнал. 2008. № 2 (52). С. 82-84.

14 Милиция и этнические мигранты: практики взаимодействия / под ред. В. Воронкова, Б. Гладарева, Л. Сагитовой. СПб.: Алетейя, 2011. 640 с.

15 Пестова Н. В. Лирика немецкого экспрессионизма: профили чужести. Екатеринбург: Изд-во УГПУ, 2002. 463 с.

16 Пранцева Г. В. К вопросу об образе мигранта в российской литературе // Буслаевские чтения: сборник научных статей по материалам VII Всероссийской научно-практической конференции с международным участием (г. Пенза, 17 апреля 2019 г.) / под общ. ред. Л. П. Перепелкиной. Пенза: Изд-во ПГУ, 2019. C. 83-88.

17 Свинкина М. Ю. «Чужесть» как лингвокультурная категория // Мир науки, культуры, образования (Горно-Алтайск). 2016. № 2 (57). С. 339-341.

18 Соломина В. В. Языковая объективация смыслового поля «свой - чужой» лексическими средствами английского и русского языков // Вестник студенческого научного общества. 2010. № 26. С. 195-198.
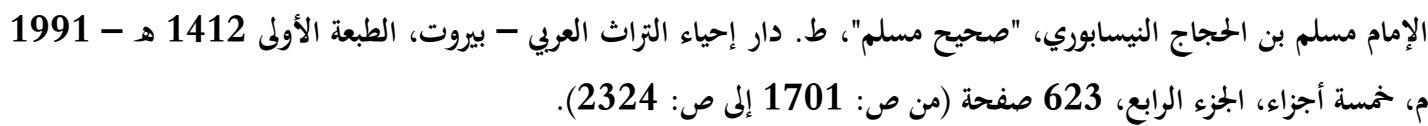

(C) 2021. Hesham M. M. Mohammed

Cairo, Egypt

\title{
"THIRD-CLASS HUMAN": \\ ON REPRESENTATION OF THE IMAGE OF ETHNIC MIGRANT IN MODERN RUSSIAN DRAMA (ON THE EXAMPLE OF THE PLAY "KHACH” BY U. B. GITSAREVA)
}

\begin{abstract}
The paper discusses artistic portrayal of an ethnic migrant in the modern Russian drama on the example of the play "Khach" (2014) by U. B. Gitsareva. The author focuses on the way migration is described and what are the meanings that inform this social phenomenon in the play. The play`s poetics is about giving a voice to migrants and distinguishing them from the mute mass, which organically fits into general tendency of Documentary Theater. The study highlights the concept of "strangeness" ("Otherness"), which is realized here both through a spatial chronotope and artistic objectivity; identifies and systematizes discursive means and mechanisms for constructing the image of an ethnic migrant, reveals perception and attitude of the host community towards the ethnic migrants, explores characteristics attributed to him in the host environment, analyzes how the topic of public recognition is embodied in everyday language and indicates strategies for migrants to overcoming "strangeness" ("otherness"). The author also substantiates the issue`s relevance for literary research. The choice of the paper's subject is determined by the lack of studies of the given issue
\end{abstract}


in terms of the modern Russian literature. As the analysis shows the play "Khach" is a comprehensive attempt at generalization, built into both the socio-psychological and ideological context.

Keywords: modern Russian drama, U. B. Gitsareva, cross-cultural communication, migration, ethnic migrant, foreign worker, migrant discourse, concept of "strangeness" ("Otherness"), mother country, foreign country.

Information about the author: Hesham M. M. Mohammed - PhD in Philology, Associate Professor, Russian Language Department, Faculty of Al-Alsun, Ain-Shams University, Al-Khalifa Al-Ma'amun St., 11566 Cairo, Egypt. ORCID ID: https://orcid. org/0000-0001-7113-1110. E-mail:maro5@mail.ru

Received: July 06, 2020

Date of publication: December 28, 2021

For citation: Mohammed H. M. M. "Third-class human": On representation of the image of ethnic migrant in modern Russian drama (on the example of the play "Khach" by U. B. Gitsareva). Vestnik slavianskikh kul'tur, 2021, vol. 62, pp. 246-257. (In Russian) https://doi.org/10.37816/2073-9567-2021-62-246-257

\section{REFERENCES}

1 Barinova A. O. Iazykovaia reprezentatsiia sobiratel'nogo obraza migranta $\mathrm{v}$ rossiiskom obshchestve [Linguistic representation of the collective image of a migrant in Russian society]. Voprosy psikholingvistiki, 2013, no 18, pp. 174-181. (In Russian)

2 Barkovskaia N. V. Pravo na golos: obraz migranta v sovremennoi russkoi poezii [The right to vote: the image of a migrant in modern Russian poetry]. Novyi filologicheskii vestnik, 2019, no 3 (50), pp. 363-376. (In Russian)

3 Bugaeva L. D. Mifologiia emigratsii: geopolitika i poetika [The mythology of emigration: geopolitics and poetics]. In: Ent-Grenzen. Intellectuelle Emigration in der russichen Kultur des 20 Jahrhunderts / Za predelami. Intellektual'naia emigratsiia $v$ russkoi kul'ture XX veka [Outside. Intellectual emigration in the Russian culture of the $20^{\text {th }}$ century], published by L. Bugaeva, E. Hausbacher. Frankfurt am Main, Peter Lang Publ., 2006, pp. 51-73. (In Russian)

4 Vesnina L. E. Metaforicheskoe predstavlenie migratsii v reaktsiiakh svobodnogo assotsiativnogo eksperimenta [Metaphorical representation of migration in the reactions of a free associative experiment]. Lingvokul'turologiia, 2010, vol. 4, pp. 31-47. (In Russian)

5 Gitsareva U. Khach [Khach]. Sovremennaia dramaturgiia, 2014, no 4 (OctoberDecember), pp. 88-102. (In Russian)

6 Gladarev B. S., Tsinman Zh. M. Militsionery i gastarbaitery: ulichnye praktiki pereraspredeleniia resursov [Police officers and guest workers: street practices of redistributing resources]. Sotsiologicheskii zhurnal, 2015, no 1, pp. 37-62. (In Russian)

7 Gordienko E. I. Neprofessionaly na professional'noi stsene: estetika obydennogo v sovremennom teatre $\mathrm{i}$ tantse [Non-professionals on a professional stage: aesthetics of the mundane in modern theater and dance]. Praktiki i interpretatsii, 2020, vol. 5 (1), pp. 82-99. (In Russian)

8 Dubin B. Rossiia nulevykh: politicheskaia kul'tura, istoricheskaia pamiat', povsednevnaia zhizn' [Zeroes 'Russia: Political Culture, Historical Memory, Everyday Life]. Moscow, ROSSPEN Publ., 2011. 391 p. (In Russian) 
9 Korobkova O. S. Markery vrazhdy v nominatsiiakh etnicheskoi prinadlezhnosti: sotsiolingvisticheskii aspekt [Markers of hostility in ethnic nominations: socio-linguistic aspect]. Izvestiia RGPU im. A. I. Gertsena, 2009, no 111, pp. 200-205. (In Russian)

10 Kosova O. A. Kommunikativnaia situatsiia otchuzhdeniia [Communicative situation of alienation: $\mathrm{PhD}$ thesis, summary]. Irkutsk, 2010. 18 p. (In Russian)

11 Litovskaia M. A. Mnogorechie v p'esakh Nikolaia Koliady: sotsial'nyi aspekt [Polyphony in the plays of Nikolai Kolyada: the social aspect]. In: Russkii iazyk v mnogorechnom sotsiokul'turnom prostranstve [Russian language in a multi-language socio-cultural space]. Moscow, Ekaterinburg, FLINTA Publ.; Izdatel'stvo UrFU Publ., 2017, pp. 206-219. (In Russian)

12 Malakhov V., Olimova S., Simon M. Tvorchestvo migrantov kak problema sotsiologii kul'tury: vykhodtsy iz Tadzhikistana $\mathrm{v}$ Rossii [The work of migrants as a issue of the sociology of culture: immigrants from Tajikistan in Russia]. Neprikosnovennyi zapas, 2018, no 3 (119), pp. 30-54. (In Russian)

13 Matvienko K. Novaia drama v Rossii: kratkii ekskurs v nedavnee proshloe i eskiz nastoiashchego [New drama in Russia: a brief excursion into the recent past and a sketch of the present]. Peterburgskii teatral'nyi zhurnal, 2008, no 2 (52), pp. 82-84. (In Russian)

14 Militsiia i etnicheskie migranty: praktiki vzaimodeistviia [Police and ethnic migrants: interaction practices], edited by V. Voronkov, B. Gladarev, L. Sagitova. St. Petersburg, Aleteiia Publ., 2011. 640 p. (In Russian)

15 Pestova N. V. Lirika nemetskogo ekspressionizma: profili chuzhesti [Lyrics of German Expressionism: Profiles of Otherness]. Ekaterinburg, Izdatel'stvo UGPU Publ., 2002. 463 p. (In Russian)

16 Prantsova G. V. K voprosu ob obraze migranta v rossiiskoi literature [On the image of a migrant in Russian literature]. In: Buslaevskie chteniia: sbornik nauchnykh statei po materialam VII Vserossiiskoi nauchno-prakticheskoi konferentsii s mezhdunarodnym uchastiem (g. Penza, 17 aprelia 2019 g.) [Buslaev readings: a collection of scientific articles based on proceedings of the VII All-Russian Scientific Practical Conference with international participation (Penza, April 17, 2019)], under the general editorship L. P. Perepelkina. Penza, Izdatel'stvo PGU Publ., 2019, pp. 83-88. (In Russian)

17 Svinkina M. Iu. "Chuzhest"” kak lingvokul'turnaia kategoriia ["Strangeness" ("Otherness") as a linguocultural category]. Mir nauki, kul'tury, obrazovaniia (GornoAltaisk), 2016, no 2 (57), pp. 339-341. (In Russian)

18 Solomina V. V. Iazykovaia ob"ektivatsiia smyslovogo polia "svoi — chuzhoi" leksicheskimi sredstvami angliiskogo i russkogo iazykov [Linguistic objectification of the semantic field "one's - another's" by lexical means of the English and Russian languages]. Vestnik studencheskogo nauchnogo obshchestva, 2010, no 2, pp. 195-198. (In Russian)

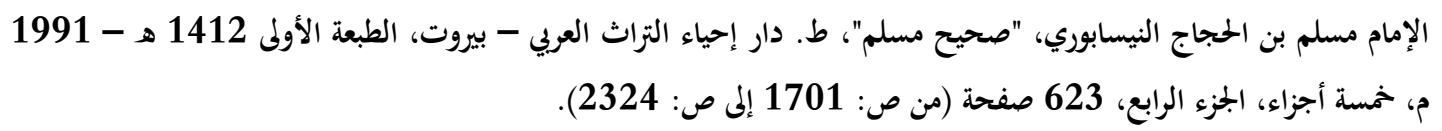

[Imam Muslim Ibn Al-Hajjaj Al-Nisaburi “Sahih Muslim”. Beirut, Dar Ihia Al-Turath Al-Arabi Publ., 1991. Vol. 4. 623 p. (1701-2324)]. (In Arabic) 